\title{
ARCHITECT AS THE SUBJECT OF CHANGE ${ }^{1}$
}

\section{DEĞíșiMIN ÖZNESI OLARAK MIMAR}

\author{
Bengi YURTSEVER \\ Mugla Sitkı Kocman University, Faculty of Architecture, Department of Architecture, Mugla / Turkey
}

ORCID ID: 0000-0003-2220-6133

Öz: Amaç: Değișim sürecinde yer alan bireyin bu sürece dahil olmak anlamında önünde iki farklı seçenek vardır: Pasif kalmak ya da aktif olmak. "Değişim" özünde dinamik olduğundan, bu hareketi daha da güçlendirmek için aktif bir pozisyonda olmak önemlidir. Bu pozisyon sorgulayan, dinleyen, kavrayan, aktaran, katılan bir yapıdadır. Tüm disiplinlerin dahil olduğu değişim sürecinde, mimarlık bundan hem etkilenen hem de etkileyen bağlamsal bir ilişki içinde yer alır. Bu nedenle mimarlık üretim ve kullanım döngüsünde aktif bir konumdadır. Çalışma kapsamında "güncel mimarlık ortamında mimar nasıl bir konumda bulunmaktadır", "bu mimarlık ortamı toplumsal ölçekte nelerden etkilenmektedir" ve "bu süreçte kalabalık insan kitlesi için üretilen mekanlar nasıl bir etki oluşturmaktadır" soruları ile mimarın durumu, tartışmayı destekleyeceği düşünülen bir manifesto ve Venedik Mimarlık Bienalleri ile bütünleştirilerek özne-nesne döngüsünde ele alınmaktadır. Yöntem: Mimar, ortamın oluşturduğu değişkenler bağlamında teorik bir vaka çalışması ile ele alınmıştır. Bulgular ve Sonuç: Bireyin ve içinde bulunduğu ortamın gücü, kolektif bilinçli bir yaklaşımın potansiyeli ile birlikte tartışılmıştır. Tartışma sonunda çeşitli sorular ve olası yeni gündemler ortaya çıkmıştır.

Anahtar Kelimeler: Geç Modernite, Küreselleşme, Kolektif Bilinç
Abstract: Aim: There are two different options for the individual involved in the process of change: To be in a position that is passive or active. As "change" is inherently dynamic, it is important to be in an active position to strengthen and make movement even more functional. This position takes the role of questioner, listener, apprehender, transmitter, and participant. In the process of change, which all disciplines are involved in, architecture has a position in which both effects, influences and sustains this situation in a contextual relationship. Therefore, the architect is in an active position in the production and usage cycle. In the study, the architect which is in the process of architectural design, within a subject-object cycle, is discussed in the context of these questions: Where is the architect located in the contemporary environment?, How is this architectural environment influenced by the social scale?, How are the effects of spaces created for the closed crowd? The discussion part is handled with Venice Architecture Biennials and a manifesto which is thought to support the main idea. Method: The architect was dealt with through a theoretical case study in the context of variables created by the environment. Results and Conclusion: The power of the individual and the environment in which they are involved is discussed in the potential of a collective consciousness approach. At the end of the discussion, various questions and possible new agendas emerged.

Key Words: Late Modernity, Globalization, Collective Consciousness

Doi: $10.17365 /$ TMD.2019.2.3

(1) Sorumlu Yazar - Corresponding Author: Bengi YURTSEVER (Dr), Mugla Sitkı Kocman University, Faculty of Architecture, Department of Architecture, Mugla / Turkey, bengiyurtsever@gmail.com, Geliş Tarihi / Received: 26.11.2018, Kabul Tarihi / Accepted: 23.08.2019, Makalenin Türü: Type of Article (Olgu Sunumu / Case Report), Çıkar Çatı̧ması / Conflict of Interest: Yok / None, Etik Kurul Raporu / Ethics Committee: Yok / None 


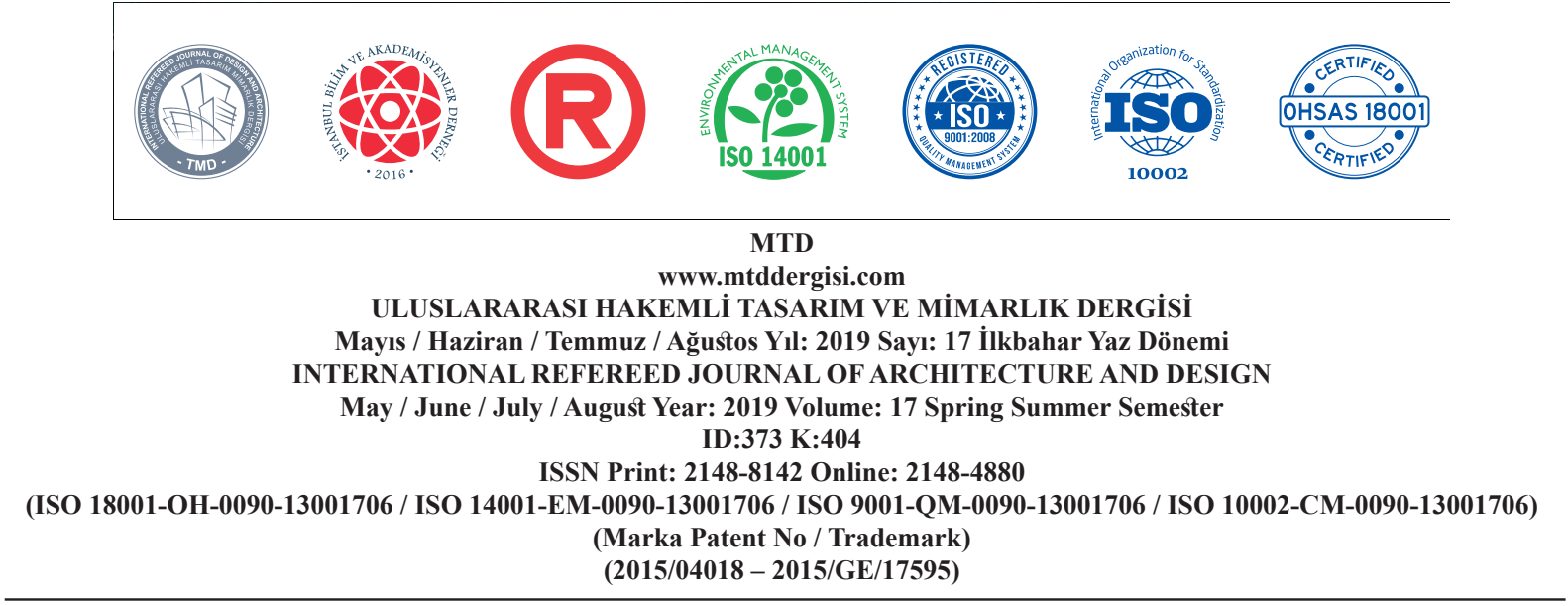

\section{INTRODUCTION}

Technology, globalization, and the dependence on them, a way of thinking that is changing, and transforming, undoubtedly affects many areas, disciplines, and lifestyles. In the context of globalization, there are many issues that can be discussed in relation to the architectural discipline. Today, where everything can easily be located and consumed everywhere, uniqueness is disappearing over time. The transformation of the location and the locality into a marketing object, which is first ignored and then transcended with itself, also affects the process of architectural design in this marketing network. The local one comes into prominence as a marketing object in this transformation (Süer and Sayar, 2002: 43). Concepts such as "meaning", "context", and "location" have lost their originality and have come to be simply jargon ${ }^{1}$ which is used for the public during the process. This jargon, a new language used to make sense of the existing one, is often a sub-language presented as meta-language (Adorno, 2012: 11). An untrustworthy perspective, a language and an understanding which conceals its own essence, has a reflection on today's architectural design process that can be handled on a large scale from production to education.

1 A specific language or vocabulary used by people in the same profession or community separately from the common denominator. http://tdk.gov.tr/

\section{RESEARCH METHOD}

Globalization debates are addressed in different disciplines with different dimensions: economic dimension, socio-cultural dimension, political dimension, geographical-ecological dimension or technological dimension. These dimensions are difficult to think of as apart from each other, but in essence, each one influences the other from a different angle. Within the scope of the study, the sociocultural dimension, and in particular its architectural reflections, were especially focused on. A discussion was undertaken through the architecture and architectural environment. A case study ${ }^{2}$ via a theoretical reading on architect and architectural understanding has been carried out considering the context of the place and the position of the individual and the point of view. As shown in Figure 1, in the developed study process in a flow, the following questions have been brought to the foreground and the scope has been expanded:

- Where is the architect located in the contemporary environment?

- How is this architectural environment influenced by the social scale?

2 The case study is a method of empirical research where a current phenomenon is used in situations where there is more than one evidence or data source in which the boundaries between the phenomenon and the content it is working within its real-life framework are not evident (Yin, 1984: 16). 


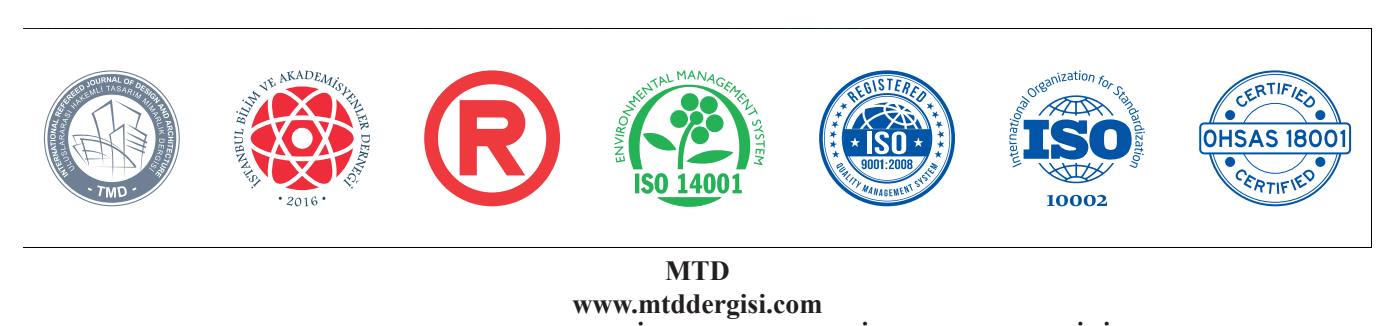

ULUSLARARASI HAKEMLİ TASARIM VE MIMARLIK DERGISİ

Mayıs / Haziran / Temmuz / Ağustos Yıl: 2019 Sayı: 17 İlkbahar Yaz Dönemi

INTERNATIONAL REFEREED JOURNAL OF ARCHITECTURE AND DESIGN

May / June / July / August Year: 2019 Volume: 17 Spring Summer Semester ID:373 K:404

ISSN Print: 2148-8142 Online: 2148-4880

(ISO 18001-OH-0090-13001706 / ISO 14001-EM-0090-13001706 / ISO 9001-QM-0090-13001706 / ISO 10002-CM-0090-13001706)

(Marka Patent No / Trademark)

$(2015 / 04018-2015 / G E / 17595)$

- How are the effects of spaces created for

the closed crowd?

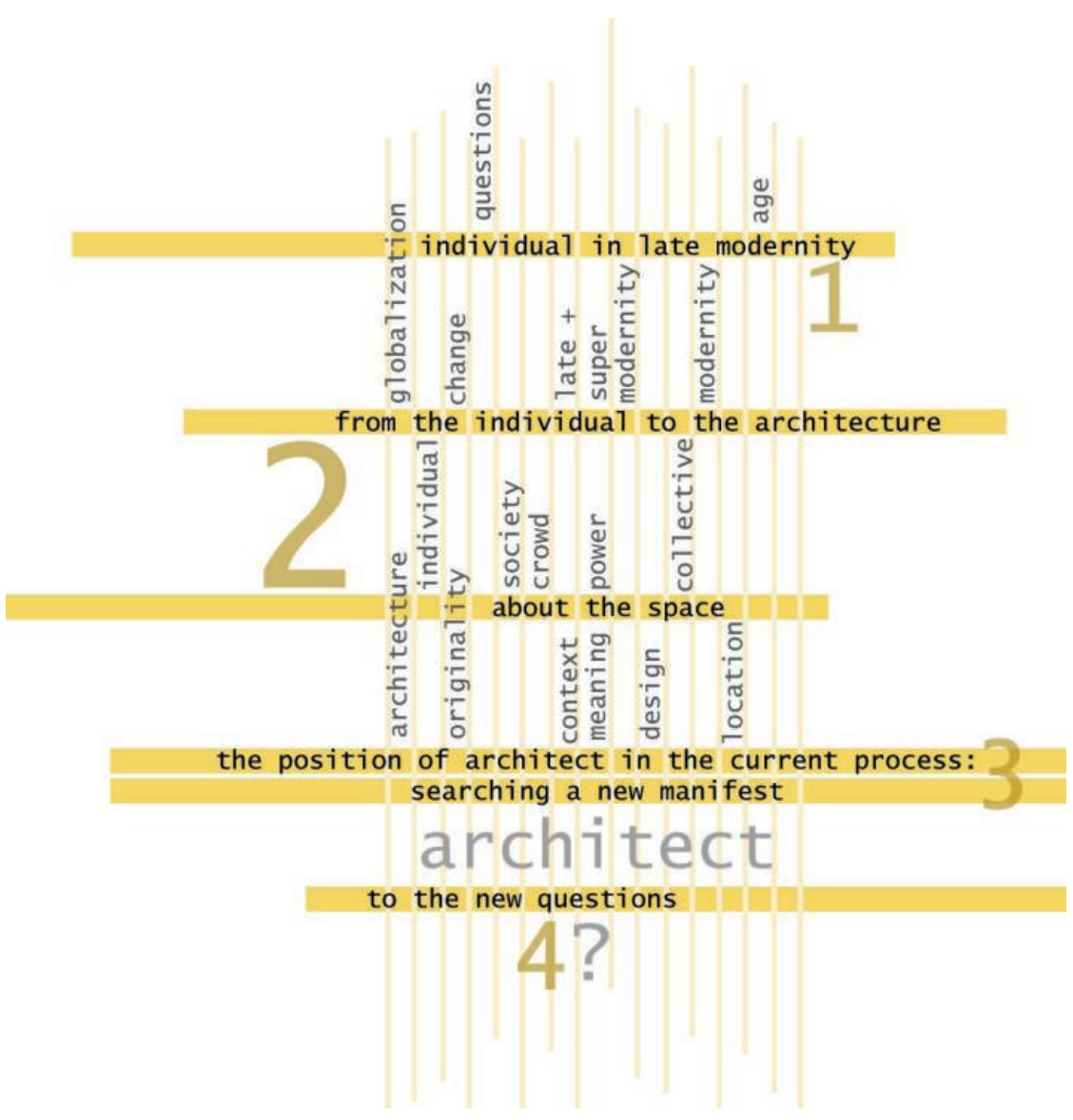

Figure 1. The Flow of Concepts

In this context, the discussion started with the

position of the individual and late modernity, which is interpreted as the contemporary environment. A deep conceptual approach was carried out for the study to reach the answers on the individual and the environment. Then it was developed from the individual with a critical approach to architecture and an artificial environment. The individual and the artificial environment were discussed in the common intellectual axis and the cyclical relations with each other were highlighted. The discussion part of the study, which is carried out through space, focuses on the architect. Therefore, according to all of the variables of the study, they were developed through late modernity, pragmatist modernist argument, individualism and space. 


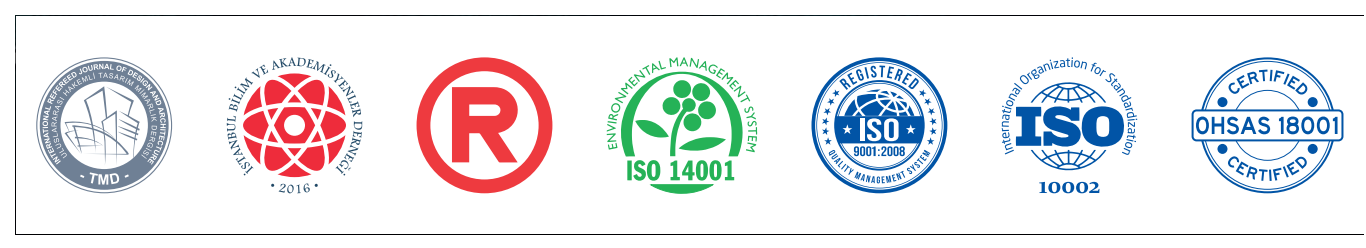

MTD

www.mtddergisi.com

ULUSLARARASI HAKEMLİ TASARIM VE MIMMARLIK DERGİİ

Mayıs / Haziran / Temmuz / Ăgustos Yıl: 2019 Sayı: 17 İlkbahar Yaz Dönemi

INTERNATIONAL REFEREED JOURNAL OF ARCHITECTURE AND DESIGN

May / June / July / August Year: 2019 Volume: 17 Spring Summer Semester ID:373 K:404

ISSN Print: 2148-8142 Online: $2148-4880$

(ISO 18001-OH-0090-13001706 / ISO 14001-EM-0090-13001706 / ISO 9001-QM-0090-13001706 / ISO 10002-CM-0090-13001706)

(Marka Patent No / Trademark)

$(2015 / 04018-2015 / G E / 17595)$

Questions were asked in this theoretical reading, interpreted in a holistic manner with the support of document analysis, conceptual mappings and observation. It has aimed to develop a discussion flow that can provide a basis for new questions rather than finding clear answers on the architect or introducing any definitions in the working process.

\section{CONCEPTUAL FRAMEWORK}

\section{Individual in Late Modernity}

"I feel I am drunk in the face of this thrilling, turbulent life that draws people into it. So many objects that pass through my eyes are feeling dizzy me. Of all these things that have affected me, there is not a single thing that wraps my heart. Still, all of them feel my feelings; so I forget what I am, what I belong to." Saint Prenx (J. J. Rousseau $\left.{ }^{3}\right)$

The loss of the natural flow of everyday life creates a static experience, despite all other conditions seeming to be accelerated. In addition, instant events place the individual in an environment that they do not need to investigate. Within instant experiences, at the point where the process has lost its importance, a community is encountered which does not care what something is or how it is being processed. Instead of its' process of how and why, this community care about only what it

3 Julie, ou la Nouvelle Heloise, 1761, 2nd Part, 14. and 17. Letters in Berman, 2013: 13 looks like at first sight from the outside (Jacobs, 2011: 27). This community, becoming increasingly indifferent to everything, firstly loses its commitment to itself and then to its environment. A life in which there is no real sense of communication or sharing dominates today, breaking away from the environment and gradually disappearing. A society that enters an environment without precisely distinguishing it, is trying to adapt to everything, but not internalize it. They adapt because it feels forced at that moment, or is thought to be "right". According to Deleuze and Guattari (2014: 61), there is no longer any individual or nature. There is only an artificial environment, and only a hierarchical structure in the process of forced production and consumption. The individual in this environment no longer has a sense of self, and is no different from a machine.

A person who is indistinguishable from a machine, can be identified among the people in a hotel lobby, a crowded human space, which Kracauer (2011: 138-149) mentioned while making his critique of everyday life. Actually, these people do not want to be there, so they hide behind each other or behind newspapers. The individual, being present in this space, is involved in a life they cannot recognize. Rather than trying to understand and experience the space, they are found here because at that moment, being present in that 


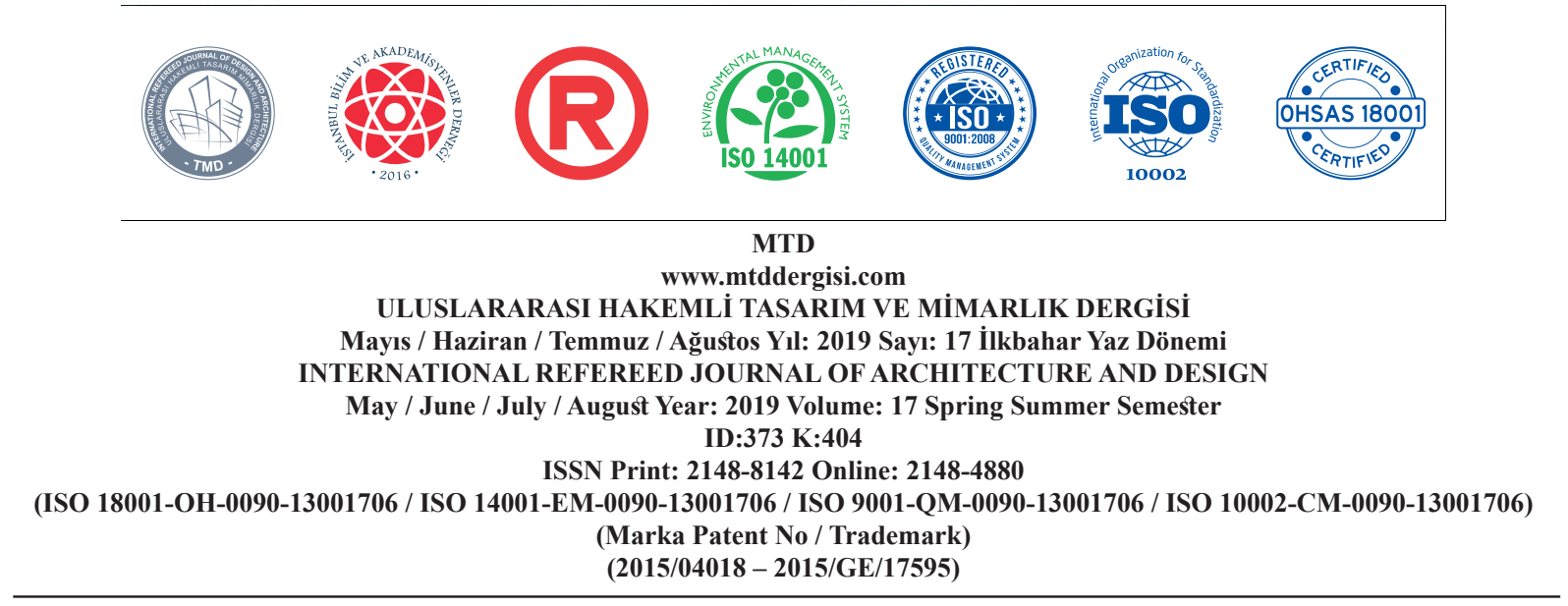

space is an indicator of something else. Individuals who are together, but who are far from sharing anything, constitute a crowd of individuals, not society. This crowd can be read as the "closed crowd" developed by Canetti (2017: 15). The closed crowd do not come together in a collective sense, but mostly through an order-obedience relationship, or with the urge to bring about this relationship. This group, which is closed against any change, does not have a structure that can use the power of being together. Therefore, meaning within the community is often not established, separated and increasingly individualized.

While meaning moves from a dimension of questioning to individuality, it makes the individual feel important from one side, on the other side creates the feeling that they have no effect on the crowd. In general, the predominant negative feelings bring a lack of personal sense of meaning, such as "the feeling that there is nothing worth doing" (Giddens, 2014-a: 20). This personal loss of meaning, which is reinforced with a break from the context and an inability to connect to something, causes the individual to become increasingly disconnected from the environment, and leaves them unable to connect with the world. The disappearance of this connection causes a non-interpretation of the past and the future and leads to pointlessness in that moment.
This situation, which oscillates between a worldview that is controlled at certain points and a worldview that has everything, requires its presence be maintained in an "essentially unstable" age. It can be argued that this point of breakthrough is developing over "individuality" (Baumeister, 1986: xiii+280). In the mentioned individual, one has got both something and nothing. They can attain or lose everything. They can inquire, maximize meaning through self-expression, and then share it, or it can get lost completely. With this unstable attitude, building a palace-like structure for this person is an extremely necessary and desired venture, but the necessity to live in it is equally unattractive (Berman, 2014: 14). The only reason for this situation that does not arise from any requirement is the indicator of the "palace" construction. Therefore, a personal lack of meaning emerges at the points where these connections cannot be established. The individual who cannot fully interpret what they have done is obliged to stay in this sense of meaninglessness. The decision-making process of the individual, who is positioned within a contradictory network within itself, is actually based on these concerns. Questioning the concerns and transforming them into curiosity may allow the conscious individual to be removed from the environment of meaninglessness. Today's society of Late Modernity, which is involved in this concern-curiosity transformation, is what 


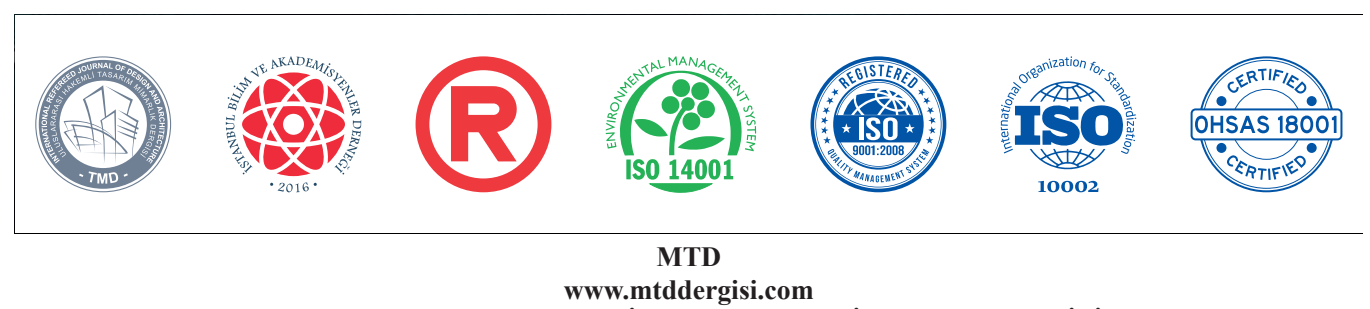

ULUSLARARASI HAKEMLİ TASARIM VE MIMARLIK DERGISİ

Mayıs / Haziran / Temmuz / Ağustos Yıl: 2019 Sayı: 17 İlkbahar Yaz Dönemi

INTERNATIONAL REFEREED JOURNAL OF ARCHITECTURE AND DESIGN

May / June / July / August Year: 2019 Volume: 17 Spring Summer Semester

ID:373 K:404

ISSN Print: 2148-8142 Online: 2148-4880

(ISO 18001-OH-0090-13001706 / ISO 14001-EM-0090-13001706 / ISO 9001-QM-0090-13001706 / ISO 10002-CM-0090-13001706)

(Marka Patent No / Trademark)

$(2015 / 04018-2015 / G E / 17595)$

Ulrich Beck (2014: 5-10) describes as a "risk society".

The concept of Late Modernity put forward by Giddens (2014-a: 13) is far from the "Post Modern" connotation, but which expresses also the after-Modern. In this period, which is dynamic from increased risks, the self is produced spontaneously according to the situation, which is reflexive, as it is in many other institutional contexts. This contradictory process, which started with Modernity on a vast scale, maintains its continuity by increasing its influence in the Late Modernity when globalization started to manifest itself in the $21 \mathrm{st}$ century. The individual is increasingly alienated from the collective they are in, and cannot analyse how the period can use its potential that originates from opposing content. According to Berman (2013: 27), today's conditions include an environment in which the living individual, with many powers, promises to transform itself and the world, while at the same time threatening to destroy everything they know.

The essence of globalization is based on the new organizational form of capitalism, which emerged as a result of the technological and institutional structure that developed with the change in the way that capital operates on a global scale (Yirtıc1, 2002: 10). This organization has a reflection in acquiring new places from production to consumption, and brings the consumption into a routine like a statute indicator for daily life. The dissatisfaction with those who are "new" increases, and even if something is taken, it cannot be owned or internalized (Ojalvo and Artun, 2014: 110). Individuals' feelings focus on the need to be differentiated from the community they are in. Differences, ephemerality, fashion, demonstrations, for instance, are at the forefront at this process. The individual in this process does not aim for being aware of what is happening and they disappear in time as an assimilated person while trying to differentiate. Therefore, consumption is moving away from an action that occurs in the direction of necessity. Consumption is no longer a free act of the individual (Yirtıc1, 2002: 11). The industry of mass consumption that the individual is involved in without questioning causes them to move away from themselves by means of the artificial processes they, themselves have created within.

The concept of globalization is considered generally in two different contexts in contemporary debate. The first is the environment that instructs how everything has to be found everywhere, and where uniformity is at the foreground, for the desired dissemination. The second one is the holistic and connected environment that develops by removing borders. In this asymmetric equilibrium, with individualization, the differences and the same 


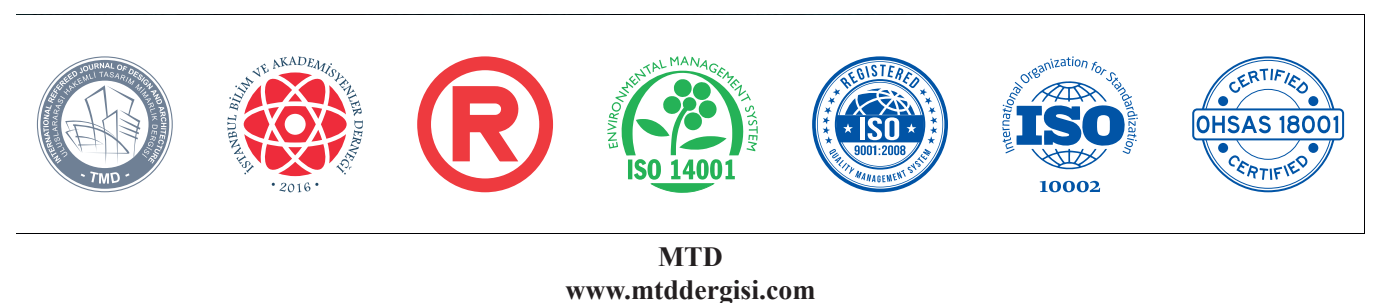

ULUSLARARASI HAKEMLİ TASARIM VE MIMARLIK DERGISI

Mayıs / Haziran / Temmuz / Ağustos Yıl: 2019 Sayı: 17 İlkbahar Yaz Dönemi

INTERNATIONAL REFEREED JOURNAL OF ARCHITECTURE AND DESIGN

May / June / July / August Year: 2019 Volume: 17 Spring Summer Semester ID:373 K:404

ISSN Print: 2148-8142 Online: 2148-4880

(ISO 18001-OH-0090-13001706 / ISO 14001-EM-0090-13001706 / ISO 9001-QM-0090-13001706 / ISO 10002-CM-0090-13001706)

(Marka Patent No / Trademark)

$(2015 / 04018-2015 / G E / 17595)$

extent of locality also manifest themselves. Robertson (1992: 8) points out that globalization has a vague structure in relation to this issue, and it refers both to the compression of the world and the intensification of consciousness of the world as a whole. The prioritised condition of being able to internalize globalization is to be able to interpret the ambiguous situation that a person has in their own circumstances.

As mentioned earlier, Modernity at the root of this vague situation can be interpreted from different perspectives. These interpretations evolved into solid polarities towards the end of the 20th century, as meaning-reducing integrations. Modernity has been interpreted in two fringe elements. People either have been tied blindly to Modernity or they have moved totally away from it. This situation, which can produce unalterable solid glances, has shifted from a flexible model to a model with stricter and more precise choices (Berman, 2013: 29). The understanding of the working process has focused on the potential of modernity and the current period. Therefore, the pragmatic approach of Modernity is at the forefront of the working process. Programmatic Modernity, which includes concepts such as emancipation, progress, and pioneering, can be thought of as a reflection of a potential of power and independence in the hands of the individual (Heynen, 2011: 25).
Giddens (2014-a: 36) states that the most important feature that distinguishes Modernity from its predecessors is extreme dynamism. The sources of this extremely dynamic nature can be seen as the separation of time and space, the development of dislocated settings, and the reflection of knowledge as reflexivity (Giddens, 2014-b: 57). The most effective one can be considered as separation of time and space. Space makes the existing context more disjointed by creating virtual relationships. Locations are now vulnerable to distant relations. These distant relationship networks are part of a structure in which the habit and experience brought about by the locality can allow it to get rid of some limitations. The interpretation of this situation is entirely individual. This situation, which can be empowered by sharing and can gain social structure, carries within it the potential to go from individuality to a larger and more understanding collective. The one-sided evaluation and interpretation of the situation focus on the negative aspects of the potential rather than the existing ones, and correspondingly the communities that are obliged to keep up with the pace and who are extremely dissatisfied are multiplying.

When thinking about it in this context, the local one is now not exactly local nor the global one exactly global anymore. These two phenomena, which continue to be affected by 


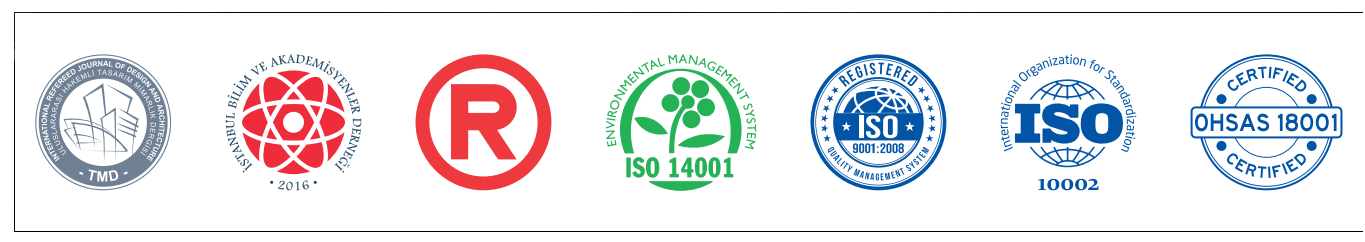

MTD

www.mtddergisi.com

ULUSLARARASI HAKEMLİ TASARIM VE MIMMARLIK DERGİSİ

Mayıs / Haziran / Temmuz / Ăgustos Yıl: 2019 Sayı: 17 İlkbahar Yaz Dönemi

INTERNATIONAL REFEREED JOURNAL OF ARCHITECTURE AND DESIGN

May / June / July / August Year: 2019 Volume: 17 Spring Summer Semester

ID:373 K:404

ISSN Print: 2148-8142 Online: 2148-4880

(ISO 18001-OH-0090-13001706 / ISO 14001-EM-0090-13001706 / ISO 9001-QM-0090-13001706 / ISO 10002-CM-0090-13001706)

(Marka Patent No / Trademark)

$(2015 / 04018-2015 / G E / 17595)$

each other, depict a contrasting seem, but an intertwined pattern. The tradition is actually one that comes out of a fundamental need and transforms with the differentiation of this requirement in the time-space dimension (Giddens, 2014-b: 42). As such, it cannot be said that it is exactly stable, because it is dependent on the ongoing condition, as it should be. The information in this context invites the events and those connected to it to break away from the settlement which they are in, to think again in a different context. The increasing separation of time and space has the potential to allow different, smaller, interventions to come to the forefront. Rather than the thought that time and space are disconnected from each other, it is much more comprehensible to interpret the situation in the form of the opening of the distance between them and to remember that this distance has a sufficiently flexible structure. Globalization is also a process of this flexibility (Giddens, 2014-b: $67)$.

Globalization and its expanding market space have the potential to enable localization to become widespread and recognizable. Giddens (2014-a; 2014-b: 27) states that the importance of individuality, the fact that the self is active, and the results and content of strong local contexts established to express oneself, are somehow contributing to and being affected by global influences. In this sense, it also refers to today's dynamism. It could have entered into a new way of thinking possibly taken by an awareness of today's potential, instead of thought trying to go back because of the idea of finding everything valuable in the past. The monotone sense of comfort that the old gives, should leave itself to a new emotion that also provides a comfortable and dynamic sense in searching for the new. Interrogation, context development, networking, and relational thinking are important actions that can make this search as active as possible.

It is thought that the "new ones" created by the combination of primitive experiences and ongoing experiences can create a curious, questioning, thoughtful, and transferring environment. The important thing is to be able to ask questions within this wide range of possibilities, and produce freely in this situation. The intention of stepping in by asking questions is the idea that subjective thinking can be expressed more easily through questions, and at the same time it can also come up with topics that can bring about different curiosities by touching on other questions and other topics.

\section{A CRITICAL APPROACH}

\section{From the Individual to the Architecture}

In the vague nature of modernity, architecture, which is defined as the need for constant "accommodation", incorporates itself into 


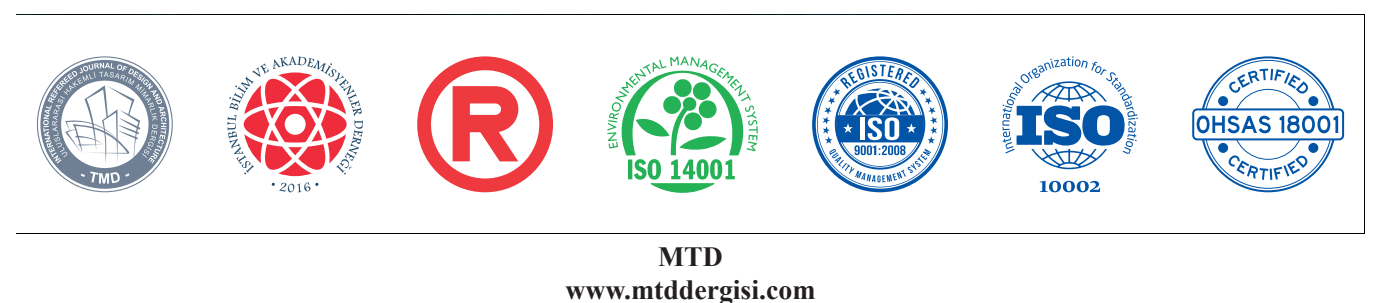

ULUSLARARASI HAKEMLİ TASARIM VE MIMARLIK DERGISİ

Mayıs / Haziran / Temmuz / Ağustos Yıl: 2019 Sayı: 17 İlkbahar Yaz Dönemi

INTERNATIONAL REFEREED JOURNAL OF ARCHITECTURE AND DESIGN

May / June / July / August Year: 2019 Volume: 17 Spring Summer Semester ID:373 K:404

ISSN Print: 2148-8142 Online: 2148-4880

(ISO 18001-OH-0090-13001706 / ISO 14001-EM-0090-13001706 / ISO 9001-QM-0090-13001706 / ISO 10002-CM-0090-13001706)

(Marka Patent No / Trademark)

$(2015 / 04018-2015 / G E / 17595)$

everyday life by focusing on location and connection. So, the thing that is done while embodying the world in which it exists, is to be involved in this concreteness (Heynen, 2011: 36). In this context, architecture creates a complete field of vague construction. It is always preferable to discuss the questions of how and under what conditions, and to discuss how to meet an understanding of architecture that brings out the essence of natural life, and the genius loci ${ }^{4}$. All professions and disciplines change over time. They gain different content and perspective. The architectural profession is one in which this change is most intense ${ }^{5}$ (İnceday1, 2005). At this point, it is an important step to understand today's space requirement and the authority of the architect candidates connected with it, and to discuss what kind of requirements are left to provide perception and time for architecture.

With the movements that emerged from the second half of the 19th century, Modernity was born in architecture and reflected the innovations in a technical sense to architecture at that time (Weston, 2015: 126). According to Karatani (2006: 13), architecture is in a series of crises. The first of these crises was named "architecture as art", which emerged

4 According to Schulz, every place has its own soul, and it belongs to that "place". The originality manifests itself at this point (Norberg-Schulz, 1980: 18)

5 http://www.mimarlikdergisi.com/index.cfm?sayfa $=$ mimarlik\&DergiSayi $=36 \&$ RecID $=612$ in the late 18 th century, and the second, "architecture as construction", and the third crisis "architecture as metaphor".

The second half of the 20th century was a period of rapid transformation of understandings on behalf of architecture. The opinion that "everything is architecture" which had emerged in the 1960s, has returned in the present day and developed close to a conceptual understanding. The confusion in this part was on the question of how architecture can differ from everything else. Over time, everything has started to emerge as an architectural product. These products have been exhibited in museums and art galleries, and have also been largely based on "surface" studies (Tschumi, 2018: 185). Accordingly, the work of the architect could be a decorative material or an exhibition material.

Architecture, which experienced a breakthrough in the 1970s, began to be adopted as a form of information, leaving pragmatic issues a little differently from its predecessor (Tschumi, 2018: 184). At this point, however, after the history reading movement became superficial, it led architecture to break away from the space-event interaction and to read the pure form figures. It was based on the idea that everything could be architecture. In the meantime, the style and analysis of the thinkers were on the agenda in all of these readings, but many of them did not go to a 


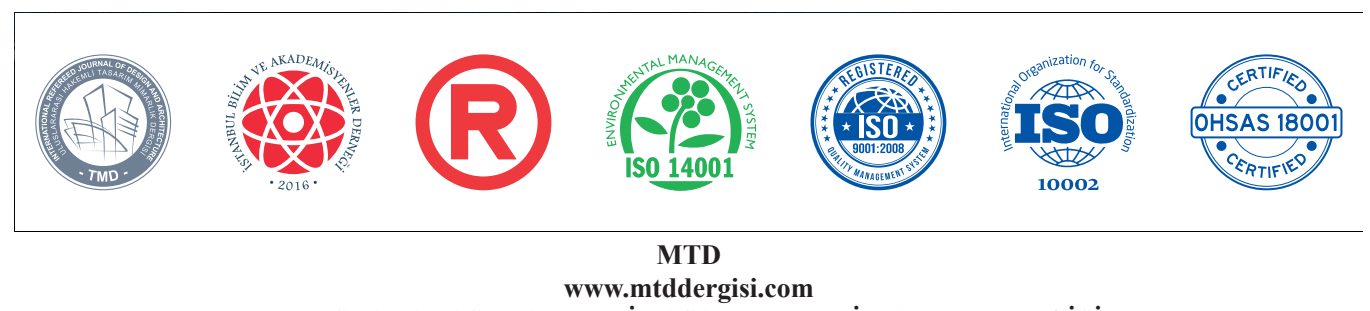

ULUSLARARASI HAKEMLİ TASARIM VE MIMARLIK DERGISİ

Mayıs / Haziran / Temmuz / Ağustos Yıl: 2019 Sayı: 17 İlkbahar Yaz Dönemi

INTERNATIONAL REFEREED JOURNAL OF ARCHITECTURE AND DESIGN

May / June / July / August Year: 2019 Volume: 17 Spring Summer Semester

ID:373 K:404

ISSN Print: 2148-8142 Online: 2148-4880

(ISO 18001-OH-0090-13001706 / ISO 14001-EM-0090-13001706 / ISO 9001-QM-0090-13001706 / ISO 10002-CM-0090-13001706)

(Marka Patent No / Trademark)

$(2015 / 04018-2015 / G E / 17595)$

different discussion from a jargon afterward, which was placed on the structure. A lot of concepts were thrown around in order to legitimize the structure. The transformation due to globalization that took place in cities especially showed itself more clearly in this period through various concepts (Özçakı, 2014). After a while they entered into life by losing their deep meaning as part of the consumer industry and globalization.

Architecture as a metaphor ${ }^{6}$, in which Berman (2013: 58) suggests strong contexts come into being where everything exists and can disappear at the same time, is nourished by its inherently contradictory environment. Architecture in this contradictory environment has been incorporated into the world of "texts" in which ideas and ideals are built up by being strengthened by analogies and metaphors to become a form of information. The written texts have increased the importance of architecture, not only its artistic sense but also the experience of the process as an architectural product (Karatani, 2006: 34).

With the coming into prominence of the process, a clear separation has appeared again. Commitment to concepts places the design to infinite freedom on one side and the architecture to an unidentified space on the other side. In essence, the architect who wants to be

$\overline{6}$ The third crisis in the process (Karatani, 2006: 14) freed from this ineffability in order to become free, reaches this aim in a different position to architecture. Hence, in the search for this identity, it could be the points where it could conflict with the architecture among the freedom of the architect (Tschumi, 2018: 53).

Occurrences in architecture are an undeniable reality. However, this "occurrence" is a meaningful fact when it has a structure coming from the combination of individualaction-space. It actually contains this in its essence. Architecture and society, which are included in artificial scenarios, artificially augment their meaning in every cycle. A society, which sees only the spaces where consumption and artificial action requirements are produced, which are disconnected from its essence, thinks that this visual is the architecture. Therefore, today's architecture is an object that is produced in contemporary consumption patterns and circulated and consumed in the system of social demonstrations (Y1rtıc1, 2002: 11).

Architectural approaches, which have lost the originality of the place, are multiplying everywhere. On the one hand, the gradual disappearance of this originality, and on the other hand, the perception determinants of today such as instant experience with consumption and advertising, also change the perception of architecture. Architectural products are now transformed into objects disconnected from 


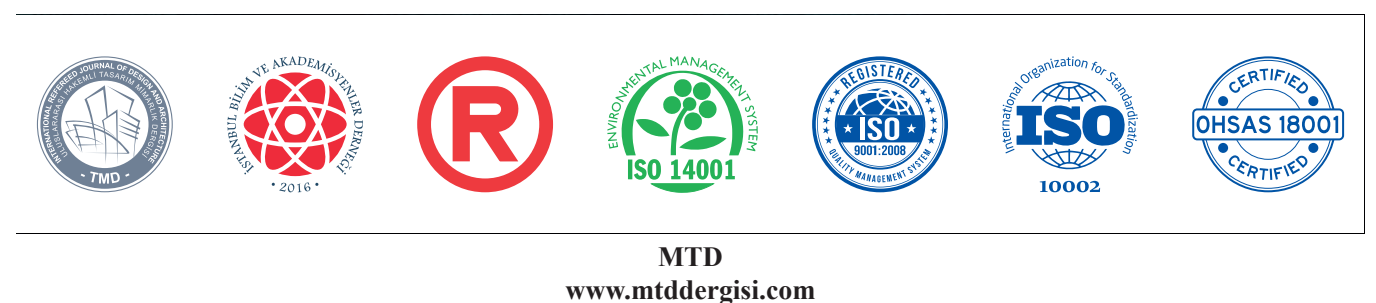

ULUSLARARASI HAKEMLİ TASARIM VE MIMARLIK DERGISI

Mayıs / Haziran / Temmuz / Ağustos Yıl: 2019 Sayı: 17 İlkbahar Yaz Dönemi

INTERNATIONAL REFEREED JOURNAL OF ARCHITECTURE AND DESIGN

May / June / July / August Year: 2019 Volume: 17 Spring Summer Semester ID:373 K:404

ISSN Print: 2148-8142 Online: 2148-4880

(ISO 18001-OH-0090-13001706 / ISO 14001-EM-0090-13001706 / ISO 9001-QM-0090-13001706 / ISO 10002-CM-0090-13001706)

(Marka Patent No / Trademark)

$(2015 / 04018-2015 / G E / 17595)$

depth and sincerity. These objects are rapidly taking place in the production-consumption cycle, and yet there is an increasing concern about their rapid disappearance. According to Uluoğlu ${ }^{7}$ (2018), the situation of an architectural product's relating to context and being personally identifiable are affected by mass production, mass consumption, becoming the same and commodification. Architectural products come in the form of advertisements, photographs, three-dimensional models or visualizations that are made under the manifestations of "determining the quality of life" of this consumption cycle. With certain places being brought to the point of attraction, the interest of the community is moving away from the locality, and is going towards the "situated everywhere". The fact that the architectural products and their approaches are far from being thought and unquestioned causes the environment to become more and more artificial every passing day. Defining the present day as Super-modernity, Auge (2016: 19) sees places as "non-space". These places cannot be defined as places to be connected. These places are ephemeral and do not carry any soul.

According to Pallasmaa (2011: 79), architectural space is a space beyond geometry, measurability, beyond physical space, and wit-

7 http://www.e-skop.com/skopdergi/mimarliginontolojisi-ve-sozde-yikimi-uzerine/586 hout the need for boundaries. Transcending borders makes it necessary to move through context without being under the influence of any linker. This context can be thought of as an infinite network maintained between "that place" and "persons". Owen" (1993), refers to design as slow reading, and consequently, describes it as a state based on the production of knowledge. This situation can be seen as a procession that results in the acquisition of dynamism in the process of access to something or natural flow instead of stasis and completeness.

A play determined its rules during action, according to Wittgenstein's (2006: 27) considerations about design. Accordingly, architects are unable to know completely the full result of their works, and no one of them will be able to break away from context. The production of architectural knowledge takes place during the game and depending on the circumstances. These can be considered using the description of Louis Kahn (2014: 21) on playgrounds. Kahn states that the concept of "a playground" does not exist for them. The playground can emerge itself in the place where it wants to be. Therefore, it is emphasized that this area is a structure that cannot be realized by special arrangement, but can be born of inspiration. This usual flow does

8 https://www.id.iit.edu/wp-content/ uploads/2015/03/Reflections-on-design-Owen_ tenjin93.pdf 


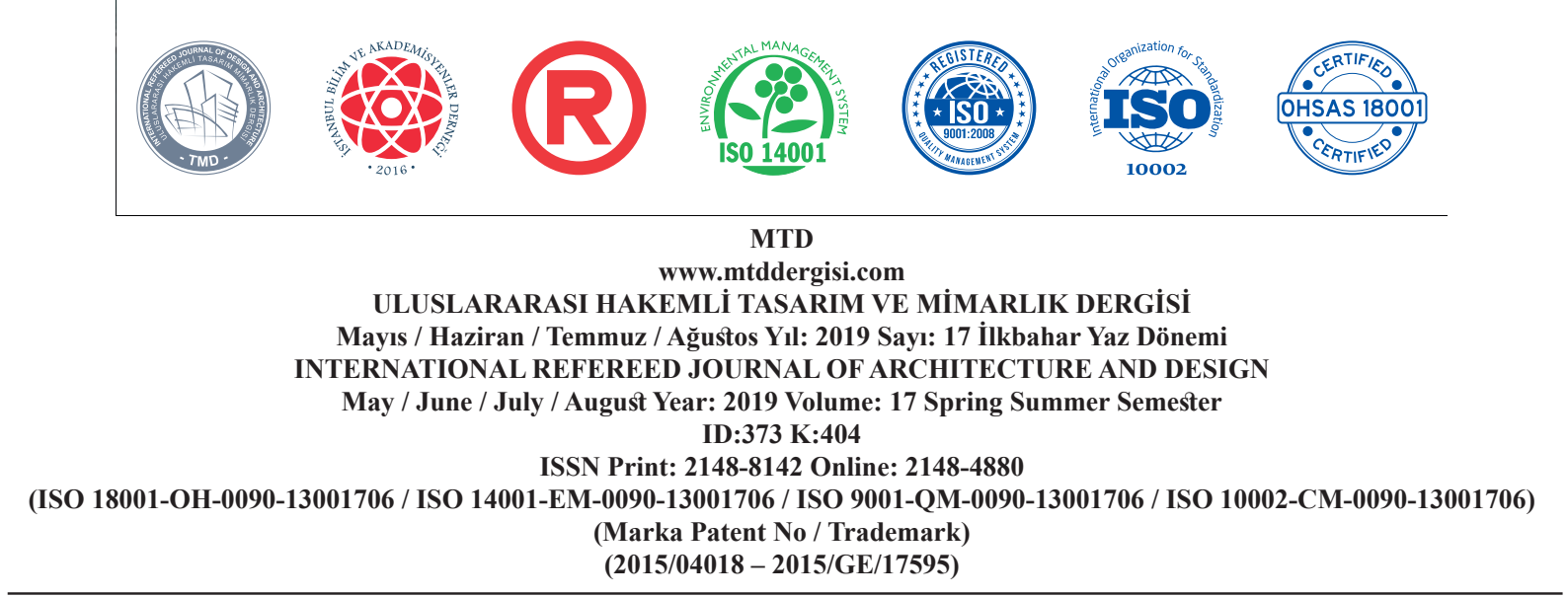

not need to reject the program. Evaluating the situation with its context brings architecture to the position of being integrated with action from the fairy tale position. So, as Tschumi (2018: 11) indicated, there will be no architecture without the program, without the action, without the event.

Beyond the concrete production of something, architecture is at a point particularly influenced by experience and other senses outside the vision. At this point, as Pallasmaa points out, architecture is drifting towards where one is positioned as an art of reconciliation between themselves and the world ${ }^{9}$. In this drift, while weaving nets between natural and artificial, a process which becomes dynamic with experience shows itself. The individual who is constantly present in the dynamic perception process is now involved in many sensory experiences that can interact with each other instead of the five classic senses. Heidegger has always kept the experience of architectural philosophy as a front-line, even if it is well suited to view today's conditions as objects of the buildings (Sharr, 2013: 3). The coexistence of architecture in the dilemma of permanence and change ensures that in the continuity of time, one is able to locate

9 In the process of becoming dynamic with the experience that is mentioned before, the task of architecture is to "make the World visible how it touch to us". Pallasmaa mentioned this for Cezanne's art (Pallasmaa, 2011: 58) itself, and in a sense become acquainted with itself. The experience that drifts from the past to the present day can find the environment of expression through architecture.

\section{About the Space}

These contradictions, including experience, and new actions that are needed depending on consumption, reveal new action and new spaces that are connected to them. The view that everything is architecture is integrated with the superficial readings of architecture. The politics of daily living such as globalization, consumption, and class distinction support this space blend, and various concepts and must-haves are introduced; so much so, that the architects in time begin to forgot that the essence of the event has been connected to these locations. Various phenomena that have disappeared during the emergence of these spaces are another issue that needs to be discussed. For example, while the inward and outward segregation is transparent with the "public space" jargon, as its contrast, the most severe reflections of privacy are noteworthy. While solid borders are moving from one side to maximize security, walls, and cameras in luxury settlements, new jargon, requirements and spaces are being produced with content, that is "we are actually in a relationship, there is absolutely no power-obedience effect here, everyone is free". While the inter-outdoor relationship was already an integral part of the 


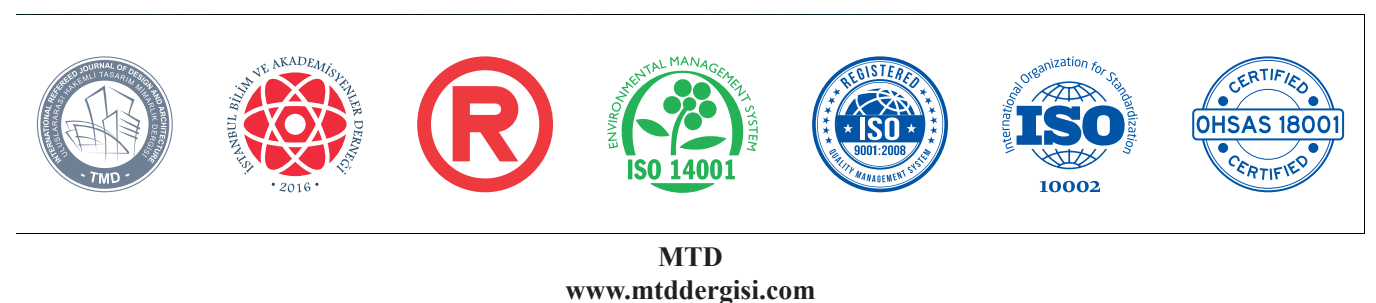

ULUSLARARASI HAKEMLİ TASARIM VE MIMARLIK DERGISİ

Mayıs / Haziran / Temmuz / Ağustos Yıl: 2019 Sayı: 17 İlkbahar Yaz Dönemi

INTERNATIONAL REFEREED JOURNAL OF ARCHITECTURE AND DESIGN

May / June / July / August Year: 2019 Volume: 17 Spring Summer Semester ID:373 K:404

ISSN Print: 2148-8142 Online: 2148-4880

(ISO 18001-OH-0090-13001706 / ISO 14001-EM-0090-13001706 / ISO 9001-QM-0090-13001706 / ISO 10002-CM-0090-13001706)

(Marka Patent No / Trademark)

$(2015 / 04018-2015 / G E / 17595)$

actions that were essentially questioned in the design process, the situation came to "luxury" in a private position. With this process of privatization, the concept of public space in many parts of the world has undergone a transformation in a way that will be negatively affected (Karaçor, 2016: 3). All these situations have started to manifest themselves as an everyday routine by objectifying themselves through a number of marketing games.

Tourism, which is part of the global economy, is also one of the most suitable sectors where the day can be pursued in terms of architecture and life. In such spaces, "leisure time" is an object of consumption and this time can only be noticed through the service there. These spaces create their own reality and create a sense of obedience to the individual (Auge, 2016: 75). At the root of this situation is an opinion that gradually moves the individual away from themselves and from producing something special for them.

Such spaces force the individual into an act, and it dictates the action rather than starting to move. While no architectural scheme can physically enable the freedom of a body's movement, a prison-like space can do so. Or a shopping mall likewise affects the individual and presses for actions within him. Foucault (1995: 278) states that such spaces are a product of power. These spaces are idealized action spaces as indicators of power, and also are the product of a mass-power confrontation. The crowd becomes involved in this life without being aware of it. They continue on their way without noticing that the action is pressure on them. At this point, Lefebvre (1991: 59) comes to mind with his discourse: You have to change the space to change your life ${ }^{10}$. The reverse, however, can also be true. So, it is possible to regard this as a cycle.

When it is approached theoretically, a collective consciousness that the individual can be active in this cycle can contribute to the change of space-life. Since the beginning of the work, the contradictory environment in which the individual has been involved, as described, is an environment in which a collective togetherness and a closed togetherness are experienced at the same time. In addition to globalization, there are many different components to the situations that cause this. Within these are economic and political components, their impact on society and the individual are seen as important. This situation reveals the concepts and lives that are at two different poles. Therefore, the current order constitutes group ruling and non-ruling. Intermediate situations exist at this level, but they are often invisible. Whereas the potential is in this intermediate situation. Being powerful is almost identical to survival. The po-

10 'Change life!' 'Change society!'. Henri Lefebvre, The Production of Space 


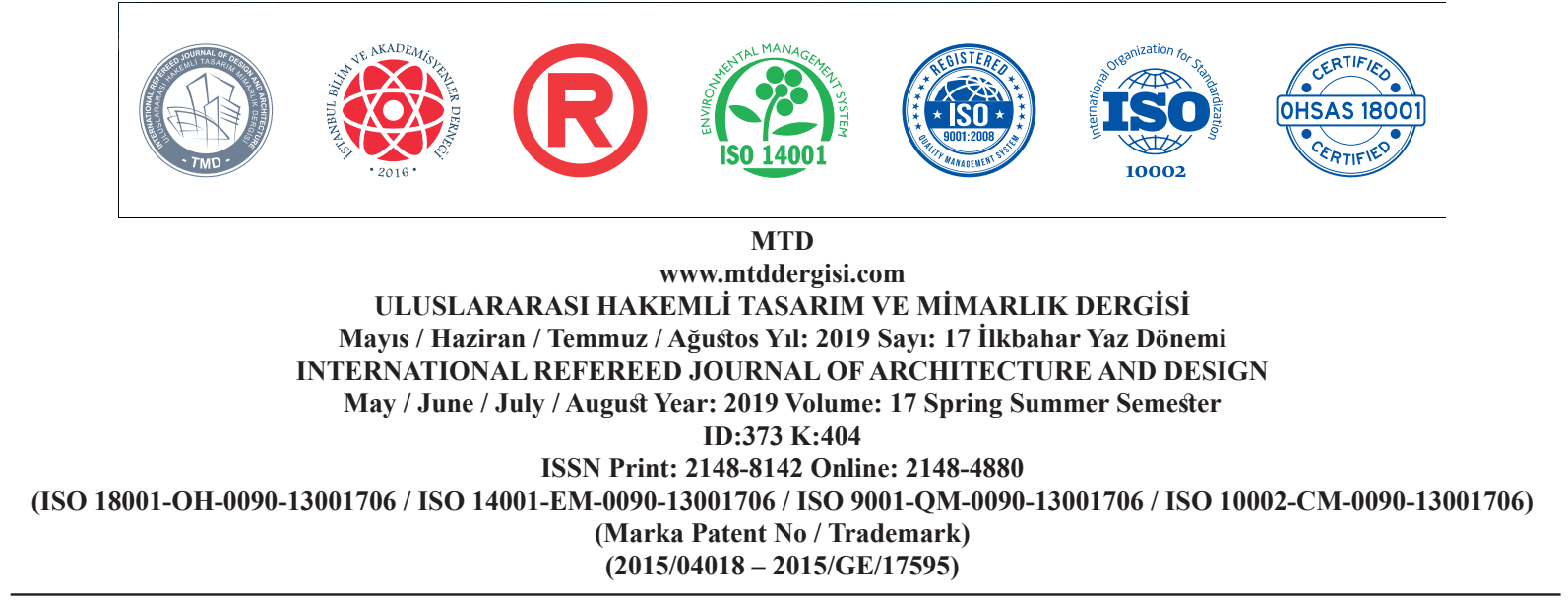

wer which is associated with spiritual death is reflected as others against it. This reflection exists beyond any political affiliation without being felt at any moment in life. The architect is different from the outside, and looks different from the outside: Different in school, different in office, different in company, different in the academic environment, and different on social media. These differences, which create a negative contradiction as well as diversity, require constant investigation of the question of what the profession is doing, what it is, and what kind of education it is involved in.

\section{DISCUSSION}

\section{The Position of Architect in the Current Process: Searching a New Manifesto}

The responses to the question "who is the architect" are also changing in response to the actions taken in daily living life. As the phases of architecture differ, the change of the "architect" is perfectly normal. Overly comprehensive, exaggerated, transcendental definitions for architecture have always been made. In the Renaissance period, the rediscovery of the texts of Vitruvius written on architecture and the information of the classical turnaround made it possible to see the architect as both a designer and a semi-artist, both involved in the process of construction and in the composition. The idea that the architect was adopted as a hero in an effort to achieve great things begins with writers like Goethe and continues with the adoption of architects such as Le Corbusier and Frank Lloyd Wright (Weston, 2015: 63). One of the biggest reasons for the occurrence of such descriptions is that architecture cannot be reduced to a one-component discipline, especially as it fulfils the requirements of living beings: Architecture has always been placed in a superior position throughout history. In addition to the engineering sciences that contain technical information, the architect must also be knowledgeable in many branches of science which are directly related to human beings such as sociology, psychology, and anthropology. They must be able to blend and interpret all of them and still maintain "self" at the end of production.

The fact that the architect's objectives do not coincide with the external architectural products has a negative effect on the process of being "self". Turner examines the position of the architect in America and states that the number of educated architects who have the chance to survive by performing their profession is decreasing day by day ${ }^{11}$ (Ross, 2016). This situation, which is seen as a known result of the day, compresses the working area of the architect to a narrow luxury housing construction. At this point, while the influence of

11 http://www.e-skop.com/skopbulten/mimarinyok-olusu/3121 


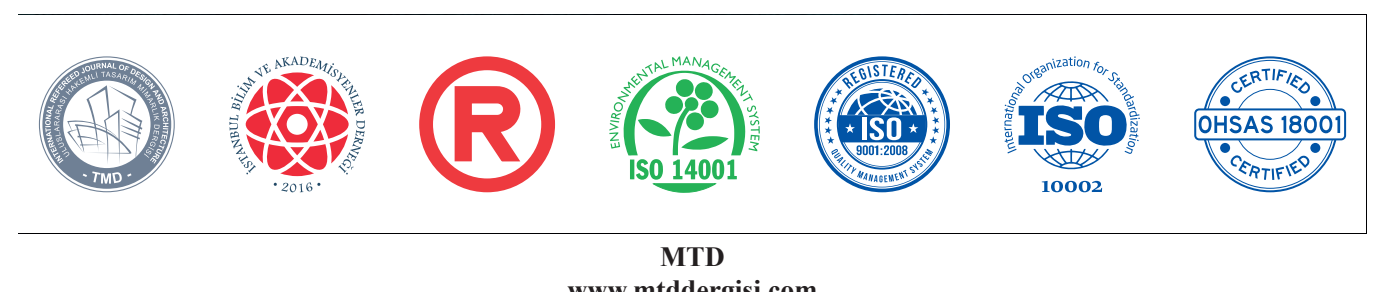

www.mtddergisi.com

ULUSLARARASI HAKEMLİ TASARIM VE MIMARLIK DERGISİ

Mayıs / Haziran / Temmuz / Ağustos Yıl: 2019 Sayı: 17 İlkbahar Yaz Dönemi

INTERNATIONAL REFEREED JOURNAL OF ARCHITECTURE AND DESIGN

May / June / July / August Year: 2019 Volume: 17 Spring Summer Semester ID:373 K:404

ISSN Print: 2148-8142 Online: 2148-4880

(ISO 18001-OH-0090-13001706 / ISO 14001-EM-0090-13001706 / ISO 9001-QM-0090-13001706 / ISO 10002-CM-0090-13001706)

(Marka Patent No / Trademark)

$(2015 / 04018-2015 / G E / 17595)$

the architect on the built environment is reduced, a few designers have still managed to reach a cultural power with incredible force. At the point where construction is overlapped with power, architecture also creates a crowd and power game within itself, and completely removes those who are not involved in the profession. This situation makes the process far from creating a collective consciousness. The process is not much different in Turkey.

With the manifestos published in the early 2000s, the suggestions of the Urban-Think Tank regarding today's problems are in a debatable position with the context of this study $^{12}$ (Figure 2). The group, which has been engaged in many interdisciplinary producti- ons since 1998, evaluates the works they do as point interventions ${ }^{13}$. They call these points "urban acupuncture" ${ }^{14}$. They also provide a variety of pressure points and intervention points to touch the problematic environment. Referring to global developments in this way, the team argues that some of the interventions they see as informal should increase, and that the essence of architecture is on the side of this informal and natural way. Instead of complaining about a number of political situations in the country as a continuous obstacle, it would be more productive to develop alternative solutions to be discussed in a collaborative and multi-faceted environment by individuals' conscious of the situations. 

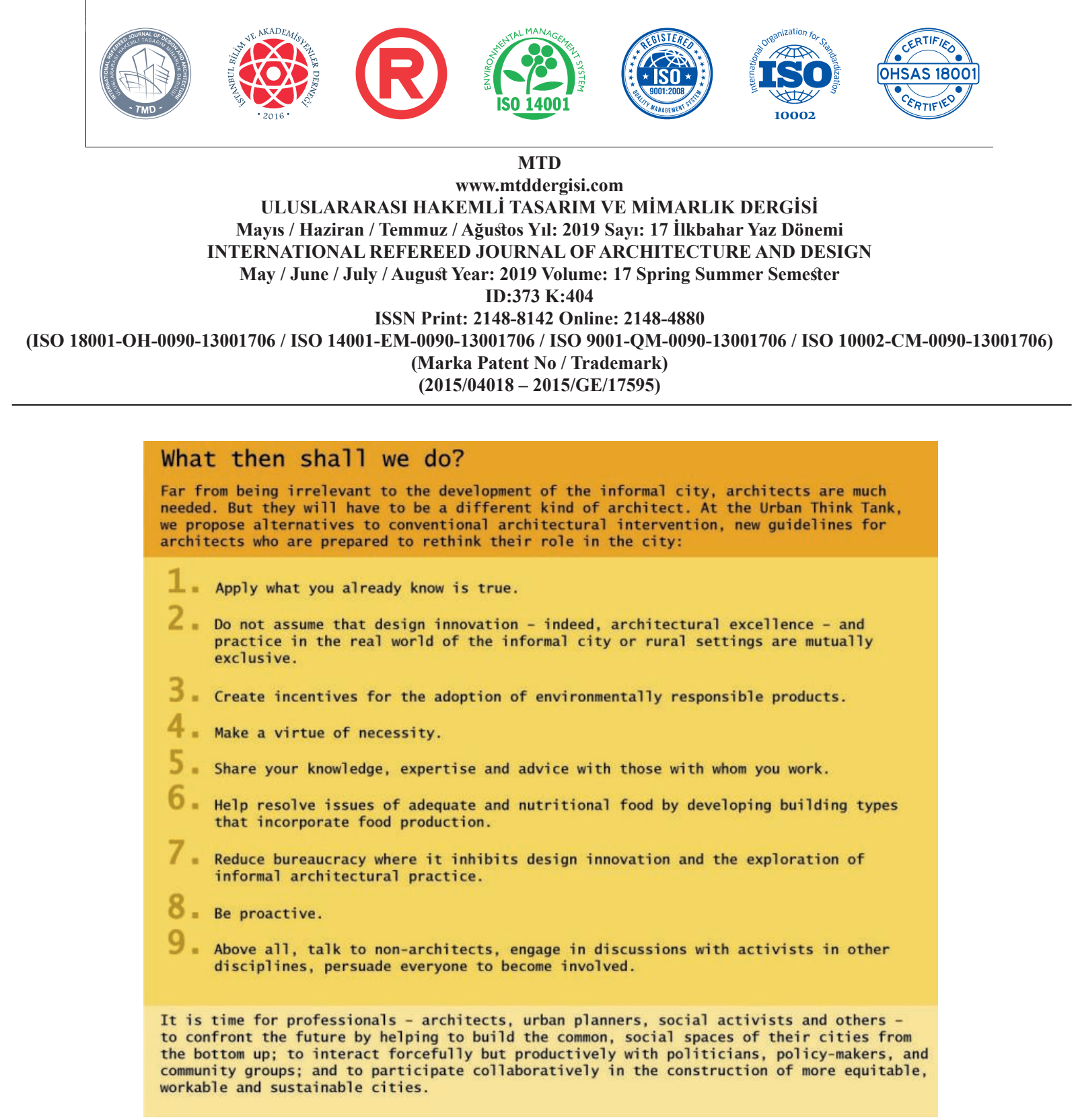

Figure 2. Urban-Think Tank Manifest (be adapted ${ }^{15}$ )

The theme of the 2008 Venice Architecture Biennial, which was also remarked upon by the Urban-Think Tank in this context, was declared as "Out There: Architecture Beyond Building"16 (Figure 3). In the context of the theme of the biennial, it was argued that before coming up with a solution to the problems, it had to be passed through a thought filter. When we came to 2018 , the main theme mo-

15 For details: https://www.iconeye.com/404/ item/3043-manifesto-\#44-urban-think-tank- |architect

16 https://www.iconeye.com/opinion/comment/ item/3834-architecture-without-buildings ved away from the subject of production and moved to a more sensual area towards the individual and humanity. Afterwards, the 2018 theme was set as "Freespace", a theme which was likely going to be the subject of curiosity $^{17}$. In the last 10 years of biennial history, with the transition of the subject to society and the city, the re-examination of the main components of architecture has been remarkable (Figure 4). In fact, this situation can be seen as a search for a constantly changing

$17 \mathrm{https}:$ / / w w w. I a bie nnale.org/en / architecture/2020 


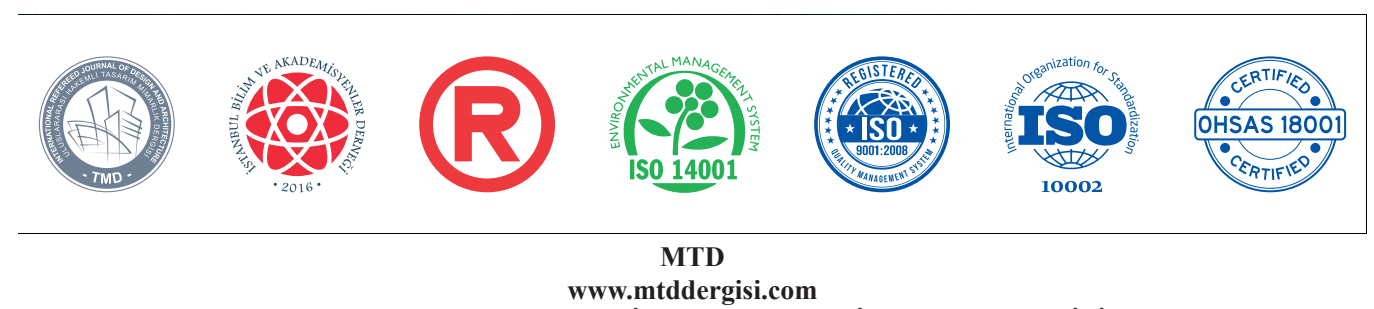

ULUSLARARASI HAKEMLİ TASARIM VE MIMARLIK DERGISİ

Mayıs / Haziran / Temmuz / Ağustos Yıl: 2019 Sayı: 17 İlkbahar Yaz Dönemi INTERNATIONAL REFEREED JOURNAL OF ARCHITECTURE AND DESIGN

May / June / July / August Year: 2019 Volume: 17 Spring Summer Semester ID:373 K:404

ISSN Print: 2148-8142 Online: 2148-4880

(ISO 18001-OH-0090-13001706 / ISO 14001-EM-0090-13001706 / ISO 9001-QM-0090-13001706 / ISO 10002-CM-0090-13001706)

(Marka Patent No / Trademark)

$(2015 / 04018-2015 / G E / 17595)$

architect. In the themes and debates, although the architect was not directly interpreted as an actor, it is a matter of, in essence, questioning and discussing in depth: What is the architect or what should the architect do today?

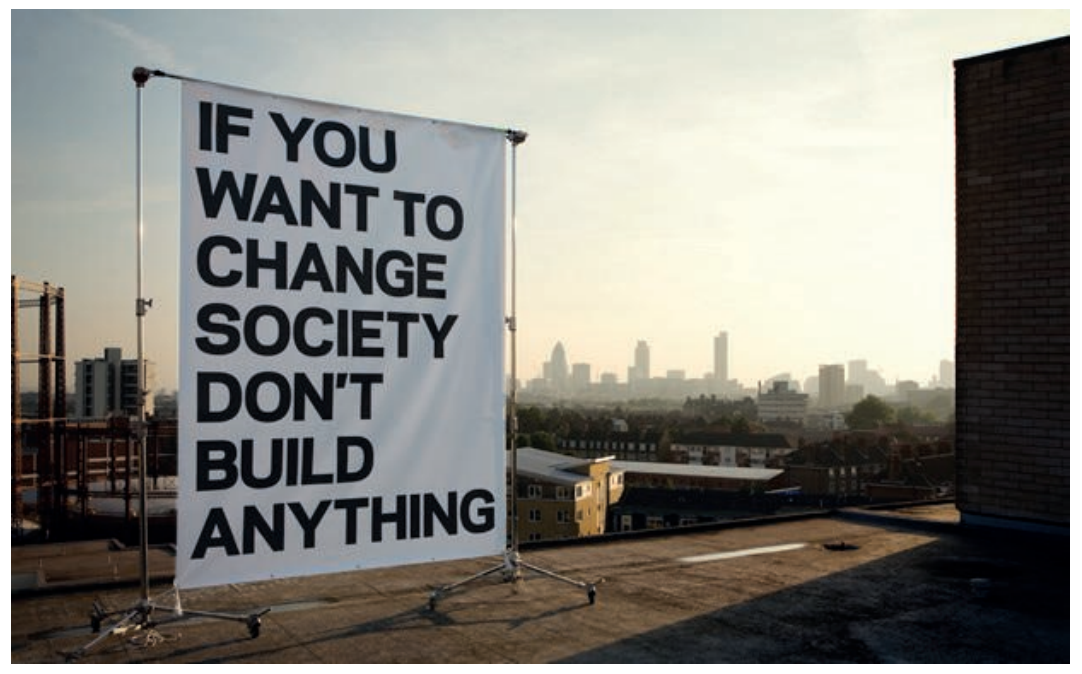

Figure 3. An Image by Guenzel, $P^{18}$

2018 freespace
2016 reporting from the front
2014 fundamentals
2012 common ground
2010 people meet architecture
2008 out there: architecture beyond building
2006 cities, architecture and society
2004
metamorph

Figure 4. Venice Architecture Biennial Themes Beginning From 2004

In this context, instead of offering a clear perspective in order to approach all potentials, there should be a more complex, ambiguous, bifurcated view that allows for a multifaceted evaluation of the situations. The research questions asked at the beginning of the study attempted to focus on and discuss the architect. In this case:

- How can an architect be free in these entire components?

$18 \mathrm{https} / / / \mathrm{www}$.iconeye.com/opinion/comment/ item/3834-architecture-without-buildings 


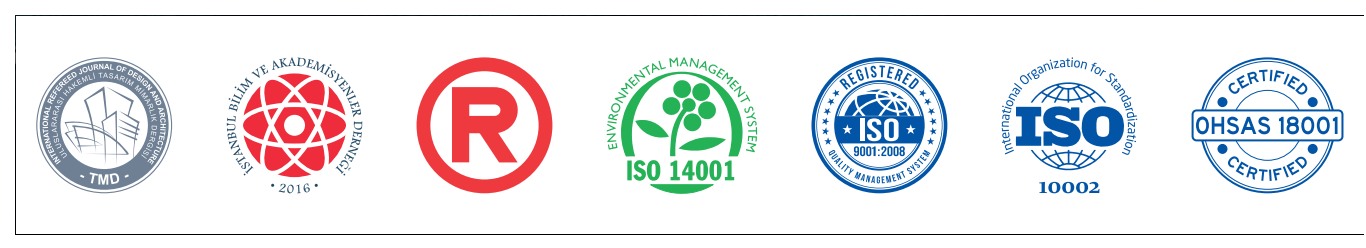

MTD

www.mtddergisi.com

ULUSLARARASI HAKEMLİ TASARIM VE MIMMARLIK DERGİİ

Mayıs / Haziran / Temmuz / Ăgustos Yıl: 2019 Sayı: 17 İlkbahar Yaz Dönemi

INTERNATIONAL REFEREED JOURNAL OF ARCHITECTURE AND DESIGN

May / June / July / August Year: 2019 Volume: 17 Spring Summer Semester

ID:373 K:404

ISSN Print: 2148-8142 Online: 2148-4880

(ISO 18001-OH-0090-13001706 / ISO 14001-EM-0090-13001706 / ISO 9001-QM-0090-13001706 / ISO 10002-CM-0090-13001706)

(Marka Patent No / Trademark)

$(2015 / 04018-2015 / G E / 17595)$

- Can architects realize the design process in the field when they are not completely free?

- Is the architect really free in formal, restrictive contexts?

- Or can this be handled within the scope of potentials?

- Is creating a self-free environment part of the design process?

\section{CONCLUSION}

\section{To The New Questions}

The questions about the architect that arise in the discussion section have the potential to be addressed in many ways. One of these potentials can be an architectural education process. The questioning can continue on this topic which is also about the position of the architect. The main reason why architectural education comes to the forefront is that this process is the first environment in which the candidate architect can express himself in the name of emancipation. The educational environment is the institution where the architect can produce manifest or even manifest itself. If this production concept is taken into consideration, a start may be made. The area of emancipation necessary for the design production process should be experienced in educational institutions where or where there may be differences with new problems. Accordingly, another discussion question should be develo- ped on the extent to which freedom can find its place in educational institutions. A discussion of the position of the architect or architect candidate in the process of architectural design education can add a different component to the study as an environment in which the transformation of the perspective to the situation discussed during the study can be achieved. Accordingly, the axis of the discussion can be based on variables such as the design education environment, the position of the executive, harmony with technology, and the mission of the training process.

The current vague period requires this to be seen as potential. This period, in which small steps can be diverted, can come to a more meaningful position with their potential interpretation. The reinterpretation of architecture may lead to a growing pattern with little touches, especially in education. The point where awareness and consciousness can develop in terms of architecture and through an "individual" is the educational environment. A wave that emerges from here and grows will be able to construct its surroundings with its own views. The architect can then be in a position to change the environment, architecture, perception, and sensitivity. This places the architect in a position where they can see the change at the point where they can touch it, rather than giving supreme power to each. The architecture that is being built and the architecture that 


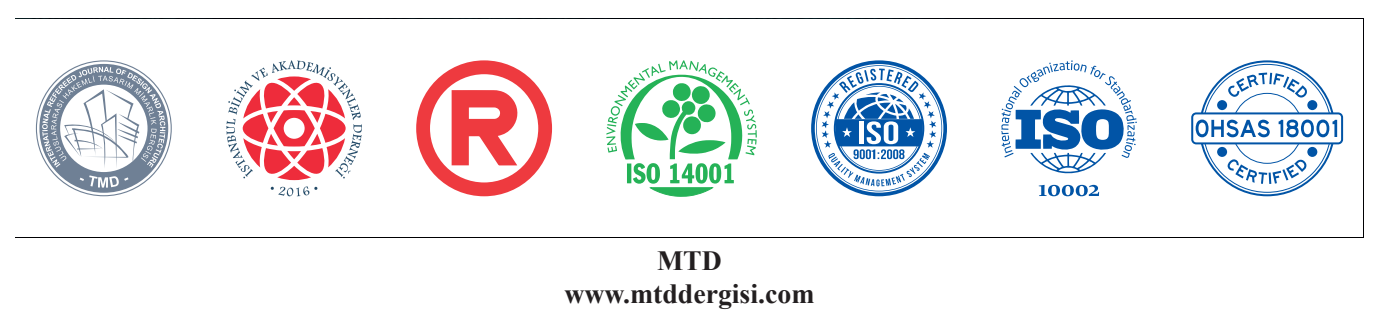

ULUSLARARASI HAKEMLİ TASARIM VE MIMARLIK DERGISİ

Mayıs / Haziran / Temmuz / Ağustos Yıl: 2019 Sayı: 17 İlkbahar Yaz Dönemi

INTERNATIONAL REFEREED JOURNAL OF ARCHITECTURE AND DESIGN

May / June / July / August Year: 2019 Volume: 17 Spring Summer Semester ID:373 K:404

ISSN Print: 2148-8142 Online: $2148-4880$

(ISO 18001-OH-0090-13001706 / ISO 14001-EM-0090-13001706 / ISO 9001-QM-0090-13001706 / ISO 10002-CM-0090-13001706)

(Marka Patent No / Trademark)

$(2015 / 04018-2015 / G E / 17595)$

is being seen have started to overlap. Thus, architecture-architectural goals and perceptions that go in different directions overlap and create a potentially liveable space that can be discussed. The city where architectural products, including communications, human relations, and sharing, take place, can reach a point where it can create its own debate and its own crowd. This crowd is a collective, an active, united body for sharing its purposes and tools; it's not a closed one. For reaching this collective consciousness, applications can be made, and then new concepts will bring different questions. Various workshops can address this set of questions that can also be touched on in design education.

When the definition of power is reinterpreted in itself it is realized that in many cases there is tangible potential. The power that can be defined as physical or rank among the highest positions should be able to turn into an awareness and an act of individual meaning. An individual-society-environment relationship, which is understood through architecture and an environmental understanding that can be transformed in the axis of this power, may arise.

Although the axis of the architect's approach in the subject of change is read through the architect, at the core of the study the architect is more general. This can be considered a research preference for the position of the axis. A more common and beneficial working principle has been adopted in order to sweep the larger area (Figure 5). Therefore, the quest for the architect in the position of the subject also looped it to move into the object position at times.
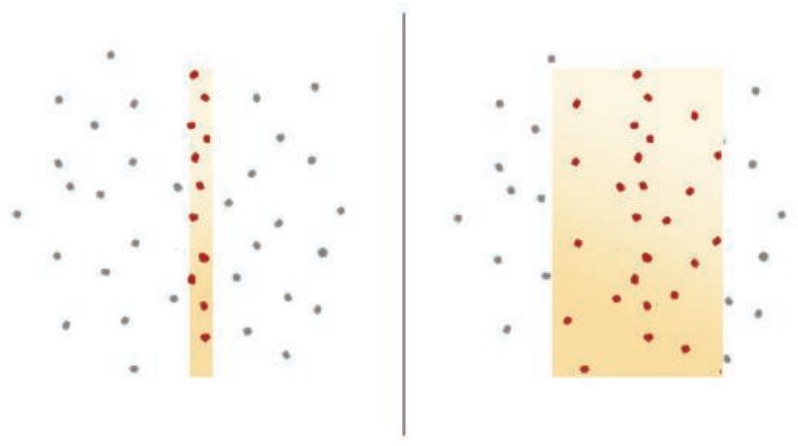

\section{Figure 5. Spread of Questioning Process According to Axis}

The subject-object cycle, which can vary its meaning in ambiguity, is in constant motion with respect to the location. While this movement imparts different meanings to the con- 


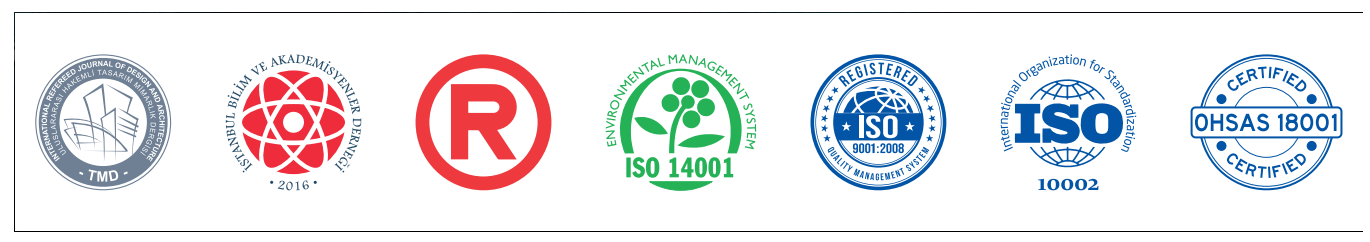

MTD

www.mtddergisi.com

ULUSLARARASI HAKEMLİ TASARIM VE MIMMARLIK DERGİİ

Mayıs / Haziran / Temmuz / Ăgustos Yıl: 2019 Sayı: 17 İlkbahar Yaz Dönemi

INTERNATIONAL REFEREED JOURNAL OF ARCHITECTURE AND DESIGN

May / June / July / August Year: 2019 Volume: 17 Spring Summer Semester ID:373 K:404

ISSN Print: 2148-8142 Online: 2148-4880

(ISO 18001-OH-0090-13001706 / ISO 14001-EM-0090-13001706 / ISO 9001-QM-0090-13001706 / ISO 10002-CM-0090-13001706)

(Marka Patent No / Trademark)

$(2015 / 04018-2015 / G E / 17595)$

cept or action, it adds different meanings to its surroundings. This understanding, which does not collapse, requires constant searching for different positions. Taking part in this quest with increasing questions will provide active participation in the architectural environment. It should be remembered that the search can be started with the smallest question/problem and it can cause manifestations, practices, transformation, change and interaction. The whole fiction of this study was developed on the basis of this point touch and propagation relationship. In this context, seeing the architect in the subject of change and sometimes as the object, and interpreting this situation from different points through different perspectives can also pave the way for new debates.

\section{REFERENCES}

ADORNO, T.W., (2012). Sahicilik Jargonu: Alman İdeolojisi Üzerine. Şeyda Öztürk (Translated), İstanbul, Türkiye: Metis Yayınlar1, s.11

AUGE, M., (2016). Yok-Yerler, Turhan Ilgaz (Translated), İstanbul, Türkiye: Daimon Yayınları, ss.19-75

BAUMEISTER, R.F., (1986). Identity: Cultural Change and Struggle for Self, New York, USA: Oxford University Press, pp. xiii +280
BECK, U., (2014). Risk Toplumu: Başka Bir Modernliğe Doğru, Bülent Doğan (Translated), İstanbul, Türkiye: İthaki Yayınları, ss.5-10

BERMAN, M., (2013). Katı Olan Her Şey Buharlaşıyor, Ümit Altuğ ve Bülent Peker (Translated), İstanbul, Türkiye: İletişim Yayınları, ss.14-27-29-58

CANETTI, E., (2017). Kitle ve İktidar, Gülşat Aygen (Translated), İstanbul, Türkiye: Ayrıntı Yayınları, s.15

DELEUZE, G., GUATTARI, F., (2014). Anti Ödipus: Kapitalizm ve Şizofreni. Fahrettin Ege, Hakan Erdoğan and Mustafa Yiğitalp (Translated), Ankara, Türkiye: Bilim ve Sosyalizm Yayınları, ss.61

FOUCAULT, H., (1995). Discipline and $\mathrm{Pu}-$ nish: The Birth of The Prison, Alan Sheridan (Translated), New York, USA: Vintage Books, p.278

GIDDENS, A., (2014-a). Modernite ve Bireysel Kimlik: Geç Modern Çağda Benlik ve Toplum, Ümit Tatlıcan (Translated), İstanbul, Türkiye: Say Yayınları, ss. 13-20-36

GIDDENS, A., (2014-b). Modernliğin Sonuçları, Ersin Kuşdil (Translated), İstanbul, Türkiye: Ayrıntı Yayınları, ss.27-4257-67 

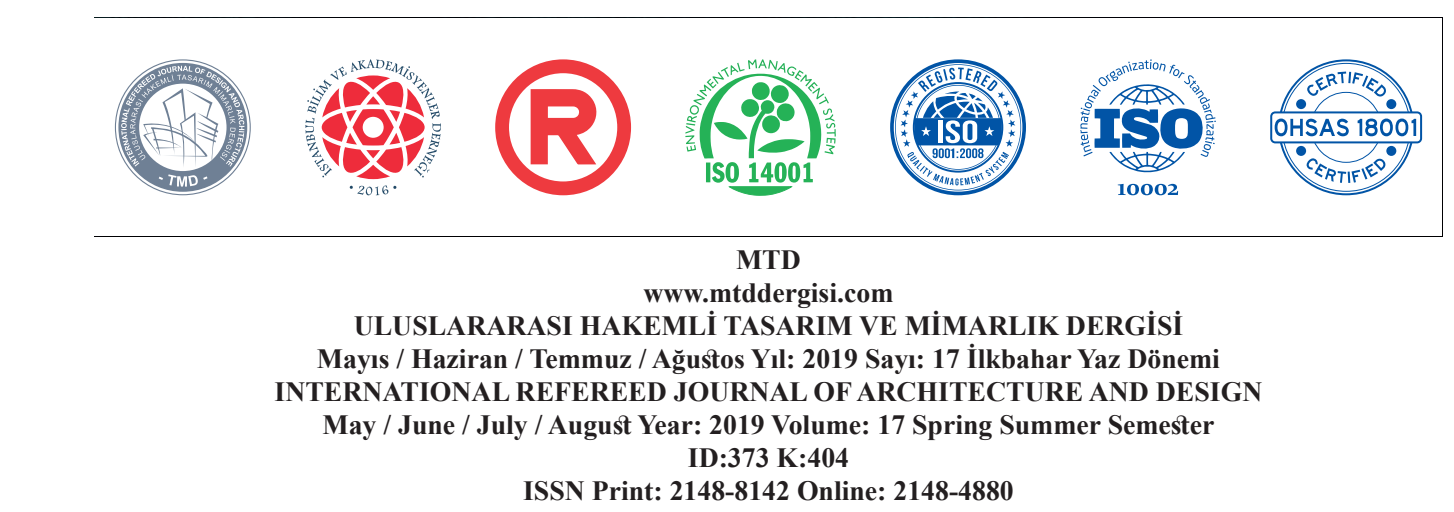

(ISO 18001-OH-0090-13001706 / ISO 14001-EM-0090-13001706 / ISO 9001-QM-0090-13001706 / ISO 10002-CM-0090-13001706)

(Marka Patent No / Trademark)

(2015/04018- 2015/GE/17595)

HEYNEN, H., (2011). Mimarlik ve Modernite: Bir Eleştiri, Nalan Bahçekapılı and Rahmi Öğdül (Translated), İstanbul, Türkiye: Versus Kitap, ss.25-36

JACOBS, J., (2011). Büyük Amerikan Şehirlerinin Ölümü ve Yaşamı. Bülent Doğan (Translated), İstanbul, Türkiye: Metis Yayınları, s. 27

KAHN, L., (2014). Öğrencilerle Söyleşiler, Nazım Dikbaş (Translated), İstanbul, Türkiye: Yem Yayınları, s.21

KARAÇOR, E.K., (2016). Özelleştirme Sürecinin İstanbul Ve New York Kamusal Mekanlarında Karşılaştırmalı İncelenmesi. TMD Uluslararası Hakemli Tasarım ve Mimarlık Dergisi, 8:1-11, Doi: 10.17365/ TMD.2016819758

KARATANI, K., (2006). Metafor Olarak Mimarlık, Barış Yıldırım (Translated), İstanbul, Türkiye: Metis Yayınları, ss.13-34

KRACAUER, S., (2011). Otel Lobisi. İçinde Kitle Süsü, Orhan Kılıç (Translated), İstanbul, Türkiye: Metis Yayınları, ss.138-149

LEFEBVRE, H., (1991). The Production of Space, Donald Nicholson-Smith (Translated), Cornwall, UK: T.J. Press Ltd, p.59

NORBERG-SCHULZ, C., (1980). Genius Loci-Towards a Phenomenology of Architecture, New York, USA: Rizzoli, p.18
OJALVO, R., ARTUN, N.A., (2014). Arzu Mimarlığı, İstanbul, Türkiye: İletişim Yayınları, s. 110

ÖZÇAKI, M., (2014). Sulukule Mahallesi'nde "Modernlik" İsteğinin İfadesi ve Etkileri. TMD Uluslararası Hakemli Tasarım ve Mimarlık Dergisi, 1(1):Doi: 10.17365/ TMD.2014019179

PALLASMAA, J., (2011). Tenin Gözleri: Mimarlık ve Duyular, Aziz Ufuk Kılıç (Translated), İstanbul, Türkiye: Yem Yayinlar1, ss.58-79

ROBERTSON, R., (1992). Globalization: Social Theory and Global Culture, London, UK: Sage Publications, p. 8

SHARR, A., (2013). Mimarlar İçin Heidegger, Volkan Atmaca (Translated), İstanbul, Türkiye: Yem Yayınları, ss.3

SÜER, D., SAYAR, Y.Y., (2002). Küresel Sermayenin Yeni Tüketim Mekanları Lüks Konut Siteleri. In Çağdaş Mimarlık Sorunları: Mimarlık ve Tüketim, 1. Bask1, İstanbul, Türkiye: Bilim ve Sanat Yayınlar1, ss.39-66

TSCHUMI, B., (2018). Mimarlık ve Kopma, Alp Tümertekin (Translated), İstanbul, Türkiye: Janus Yayınları, ss.11-53-184-185

WESTON, R., (2015). Mimarlığı Değiştiren 100 Fikir, Neslihan Işık (Translated), İs- 


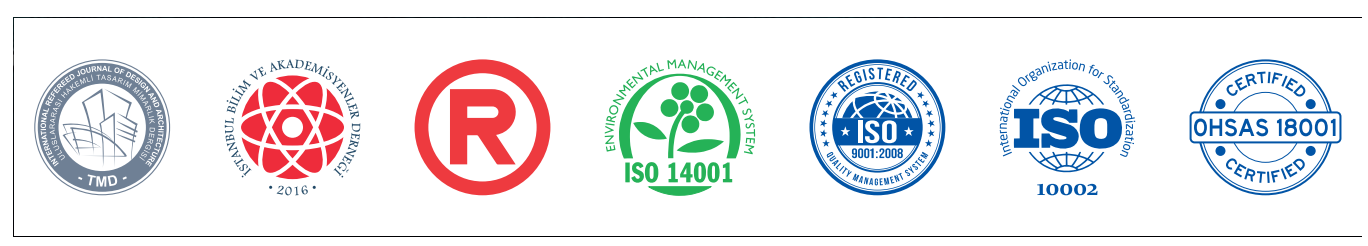

MTD

www.mtddergisi.com

ULUSLARARASI HAKEMLİ TASARIM VE MIMMARLIK DERGİİ

Mayıs / Haziran / Temmuz / Ağustos Yıl: 2019 Sayı: 17 İlkbahar Yaz Dönemi

INTERNATIONAL REFEREED JOURNAL OF ARCHITECTURE AND DESIGN

May / June / July / August Year: 2019 Volume: 17 Spring Summer Semester ID:373 K:404

ISSN Print: 2148-8142 Online: $2148-4880$

(ISO 18001-OH-0090-13001706 / ISO 14001-EM-0090-13001706 / ISO 9001-QM-0090-13001706 / ISO 10002-CM-0090-13001706)

(Marka Patent No / Trademark)

$(2015 / 04018-2015 / G E / 17595)$

tanbul, Türkiye: Literatür Yayıncılık, ss.63-126

WITTGENSTEIN, L., (2006). Felsefi Soruşturmalar, Deniz Kanit (Translated), İstanbul, Türkiye: Totem Yayıncılık, s.27

YIN, R., (1984). Case Study Research: Design and Methods, California, USA: Sage Publications, p.16

YIRTICI, H., (2002). Tüketimin Mekansal Örgütlenmesinin İdeolojisi. In Çağdaş Mimarlık Sorunları: Mimarlık ve Tüketim, 1. Bask1, İstanbul, Türkiye: Bilim ve Sanat Yayınları, ss.9-38

\section{INTERNET SOURCES}

INCEDAYI, D., (2005). Arabulucu Olarak Mimar: Sosyal Politika Platformunda Mimarlık, Mimarlık Dergisi, 323. http:// www.mimarlikdergisi.com/index.cfm? say fa $=$ mimarlik $\&$ DergiSayi $=36 \&$ Rec $\mathrm{ID}=612($ Accessed 2.09.2019)

OWEN, C., (1993). Reflections on Design: Process for Change. https://www. id.iit.edu/wp-content/uploads/2015/03/ Reflections-on-design-Owen_tenjin93. pdf. (Accessed 2.09.2019)
ROSS, A., (2016). Mimarın Yok Oluşu, Elçin Gen (Translated), Skopdergi. http:// www.e-skop.com/skopbulten/mimarinyok-olusu/3121 (Accessed 2.09.2019)

ULUO $\breve{G} \boldsymbol{L} U, B$., (2012). Mimarlığın Ontolojisi ve Sözde Yıkımı Üzerine, Skopdergi, 2. http://www.e-skop.com/skopdergi/ mimarligin-ontolojisi-ve-sozde-yikimiuzerine/586 (Accessed 2.09.2019)

GALILEE, B., (2007). URBAN Think Tank, Icon 048, June 2007. https://www.iconeye.com/opinion/comment/item/2390urban-think-tank-\%7C-icon-048-\%7Cjune-2007 (Accessed 2.09.2019)

GALILEE, B. Architecture Without Buildings. https://www.iconeye.com/opinion/comment/item/3834-architecturewithout-buildings (Accessed 2.09.2019)

https://www.iconeye.com/404/item/3043manifesto-\#44-urban-think-tank-|architect (Accessed 2.09.2019)

http://u-tt.com/ (Accessed 25.03.2019)

https://www.labiennale.org/en/architecture/2020 (Accessed 02.09.2019)

http://tdk.gov.tr/ (Accessed 02.09.2019) 